\title{
The Violence Against Women During the COVID-19 Pandemics
}

\author{
Diana Stoica
}

Faculty of Journalism and Communication Sciences, University of Bucharest

\section{Насилието срещу жени по време на пандемиятя COVID-19}

\author{
Диана Стойка
}

Факултет по журналистика и комуникационни науки, Университет в Букурещ

\section{Author Note \\ Diana Stoica (iD) https://orcid.org/0000-0001-9051-7086}

The author has no known conflict of interest to disclose.

Correspondence concerning this article should be addressed to Diana Stoica, Faculty of Journalism and Communication Sciences, University of Bucharest, 1-3 Iuliu Maniu, Building A, 6th Floor, Bucharest, 061071. Email: dyana.stoica@yahoo.com

\section{Бележки за автора}

Диана Стойка

https://orcid.org/0000-0001-9051-7086

Авторът няма конфликт на интереси.

Адресът за кореспонденция с автора е Факултет по журналистика и комуникационни науки, Университет в Букурещ, 1-3 Iuliu Maniu, сграда А, 6-ти етаж, Букурещ, 061071. Email: dyana.stoica@yahoo.com 


\begin{abstract}
One of the biggest crises of the modern world - the COVID-19 pandemic - brought with itself new measures to be implemented all around the world. The lockdowns imposed to prevent the spread of the virus affected terribly numerous aspects of everyday life but mainly created a hidden pandemic indoors. The purpose of this paper is to underline the impact of the COVID-19 pandemic in what concerns the violence against women (VAW). Although it might seem early for estimating the damages produced in this area of study, there can be envisaged many statistics, a lot of system weaknesses, and possible solutions to help the victims. This article aims to resume the whole chaos installed on the Globe behind the closed doors, in the family - the most intimate place, where the joy and the love should dominate.
\end{abstract}

Keywords: domestic violence, women, coronavirus, pandemic, lockdown

\title{
Резюме
}

Една от най-големите кризи в съвременния свят - пандемията COVID-19 - донесе със себе си нови мерки, които да бъдат приложени по целия свят. Заключванията, наложени, за да се предотврати разпространението на вируса, засегнаха по ужасен начин множество аспекти от ежедневието, но създадоха главно скрита пандемия на закрито. Целта на настоящата статия е да подчертае въздействието на пандемията на COVID-19 по отношение на насилието над жени (VAW). Въпреки че може да изглежда рано за оценка на щетите, нанесени в тази област на изследване, биха могли да се вземат предвид статистики, много системни слабости и възможни решения, за да се помогне на жертвите. Тази статия цели да преосмисли целия хаос, инсталиран на земното кълбо зад затворените врати в семейството - най-интимното място, където радостта и любовта трябва да доминират.

Ключови думи: домашно насилие, жени, коронавирус, пандемия, заключване

ARTICLE INFO: Original Article Received: $15,09.2020$ Revised: 30, 09.2020 Accepted: 17, 10.2020 


\section{The Violence Against Women Auring the COVID-19 Pandemics}

For a long time already, violence against women (VAW) represents one of the world's major problems. The desire and the pleasure of powerful people to dominate the smaller and unprotected ones are already known worldwide. In our case, the syntagma, the smaller and unprotected ones, can be translated into women, children, and elders. Generally speaking, men are those who try to impose their power in society: in the political arena, in the economic spheres, in what concerns the domain of engineering, of motoring, of information technology, or in what interests the legal professions, such as judges, lawyers or magistrates. But many of these men tend to impose their so-called power even at home, with their wives, girlfriends, children, most of them believe - even in the XXIst century - that patriarchate is the 'right' response to maintain a 'healthy' relationship and the 'natural order.' This power is manifested in various forms, and these forms may exacerbate during periods of crisis, such as the COVID-19 pandemics.

\section{COVID-19 - General Context}

At the end of 2019, a new kind of virus appeared in Wuhan, a Chinese city located in its eastern part. The official name - severe acute respiratory syndrome coronavirus 2 (SARS-CoV-2) - "was given by the International Committee on Taxonomy of Viruses based on phylogenetic analysis" (Liu et al., 2020, p. 328). The new infection demonstrated that it could spread rapidly all around the world. As the medical personnel began to investigate and analyze the factors that contribute to the spread of the disease, it was envisaged that "the virus jumps between people who are in very close contact with each other" (Wetsman, 2020). So, it was observed that if an infected person coughs or sneezes close to other persons, he/ she may infect them. The main measure taken by the Chinese Government in order to combat what seemed to be an epidemic was the lockdown. But because of the constant increase of the cases not only in China but around the world, "on March 11, 2020, the WHO officially declared the COVID-19 outbreak a pandemic" (Reynolds \& Weiss, 2020). For the purposes of this review, it is mandatory to include also the definition of a pandemic: "an epidemic occurring over a very wide area, crossing international boundaries, and usually affecting a large number of people" (Porta, 2016). Due to this fact, many European, American, Asian, and African countries began to impose lockdowns in order to protect the citizens from getting sick. The European epicenter of the virus was Italy, and then, after a few weeks, the United States of America started to be in the leading place in what 
concerns the number of patients. Schools and kinder gardens were closed, and many people began to work from home or, in many cases, lost their jobs. The situation became quickly more and more complicated and critical. As soon as the Governments tried to maintain the population safe and sound and prevent the spread of the virus outdoors, a new silent but powerful pandemic started indoors.

\section{'Unseen' crises appear during the state of emergency or disasters.}

During the COVID-19 pandemic, it was perceived as an increase in what concerns the number of domestic violence cases in most countries. Researchers remarked that during difficult periods, when natural disasters such as hurricanes, earthquakes, tsunamis occur, people's conduct tends to be more violent towards the family and particularly towards women (wives, girlfriends, daughters, mothers, etc.). This type of behavior was also seen "after the 29 "Black Saturday" bushfires in Australia and 20107.0 magnitude earthquake in Haiti" (Campbell, 2020). Also, "in the aftermath of Hurricane Katrina, one study reported a fourfold increase in rates of genderbased violence, primarily driven by a partner violence, among displaced women in Mississippi" (Kofman \& Garfin, 2020, p. 1998). At the same time, during the Ebola outbreak, "an epidemic of rape, sexual assault, and violence against women" (Peterm et al., 2020) was perceived in the whole territory of West Africa. Likewise, the statistics have shown that "during the Zika outbreak, gender inequalities increased and women were the most vulnerable from the socioeconomical perspective" (Wenham et al., 2020). Doctors, lawyers, psychologists, and experts indicated that besides the higher number of domestic violence cases, the acts of violence became more and more cruel and terrible during emergencies. So, the place that should be the most comfortable and pleasant should protect and support converts into a nightmare reality.

\section{The impact of the lockdown and quarantine over the population}

The obligation to remain indoors may, at first, appear quite simple to respect, but over a long period, it becomes a real burden for everybody. The studies underlined that there could be envisaged some characteristics of those persons who were quarantined. First, it should be noted that the "post-traumatic stress level is higher, as well as the level of emotional disturbance, the irritability, the depression, the anger, and the emotional exhaustion" (Brooks et al., 2020, p. 913). Nevertheless, people who were quarantined because they entered in contact with persons who might have the virus indicated that they began to feel nervous, guilty, sad, and frightened. They 
constantly thought that they might develop either a mild form of the virus or a complication and these ideas, together with the constant tension of not sickening the loved ones, affected their mental health. After the quarantine period, people reported that they felt stigmatizing attitudes from the part of the others who were not quarantined. The media and the insufficient information presented about the disease in an understandable manner for all people's categories contributed to these behaviours.

On the other side of the problem, the lockdown imposed in many countries created troubles in many families. The parents began to work from home and the children to get more accustomed to online schooling. There were reported many cases in which people lost their jobs due to the pandemic. These rapid changes imposed in order to combat the medical crisis have destroyed, in some situations, the peaceful familial climate and have let the dominator exercise his control in a new way. The continuous panic created on the TV, on the radio, on Facebook affected the citizens. The medical system also cracked: many hospitals were receiving only people infected with the new virus, and the other patients could not benefit from medical assistance. The senior citizens encountered difficulties in what concerns food and medicine supply because of the authorities' restrictions (only two hours per day out of the house for shopping, medical care, etc.). The general situation with all the new measures was hard to manage for many citizens, especially women, girls, and children.

\section{The domestic violence - general aspects}

For many years, international organizations, national experts, and associations have tried to find out a definition that states clearly and precisely what means an act of VAW. Finally, in 1993, the General Assembly of United Nations indicated, throughout the Declaration on the Elimination of Violence against Women, a version that grasps all the important aspects: "Any act of gender-based violence that results in, or is likely to result in, physical, sexual or psychological harm or suffering to women, including threats of such acts, coercion or arbitrary deprivation of liberty, whether occurring in public or in private life." (Center to End Violence against Women and Girls, 2010).

Some people believe that VAW is considered a phenomenon that affects only those having a low level of education or insufficient financial means. This represents one of the myths of domestic violence. VAW affects all the categories of people. It is a scourge that sneaks 
recklessly in many families, even though they are perceived as the high-educated class or the rich category. Another myth is that the violent men are alcoholics: alcohol can contribute, but it is not the trigger in this situation. It was demonstrated that only "50\% of the violent men have trouble with the alcohol" (Welzer-Lang \& Daniel, 2005, p.64). The rest of them manifest violent behaviours even though they do not consume alcohol. Also, many people consider that domestic violence represents a psychiatric disease. If this aspect is true, then there would be envisaged a precise scheme of treatment that could heal the disease. However, the studies indicate that the violence is not an illness, but a situation in which the husbands' tensions and dissension reached the maximal point. At the same time, many people consider that the violent man lost his control, and because of this fact, he acted wrongly. Using the phrase lose control, we eliminate any culpability trace concerning men. "The man lost his control" due to the fact that the woman "did something wrong" are the stereotypical judgments (present in the news and everyday conversation) that mean "blame the victim" and deculpabilize the perpetrator. The violent man cannot be defended by considering that he suffered a loss of control: he only "suffers" when his partner tries to manifest her freedom.

Many men, especially those who consider that patriarchy represents the best system that can offer them liberty, power, and complete domination, perceive the women as inferior human beings who cannot have and must not have the same rights as them. In this sense, the term minoritization defines very well their behaviors: "treating women as lesser beings and relegating them to the realm of the intimate, the private, the particular, treating theirs as minority issues" (Segato, 2016, p. 615). These ideas can be observed mostly in rural spaces and in areas where the population is mostly concerned with respecting traditions and customs.

The annual studies and researches have shown that approximately $30 \%$ of women around the world are victims of different types of domestic violence: either economic, or verbal, or psychological, or physical, etc. The perpetrator might be the actual partner or an ex-intimate partner. In these conditions, it is clearly that home can be one of the most dangerous places for women, even though it should be the space (oasis, heaven) of love.

These types of conduct multiply in difficult situations, such as natural disasters, epidemics, pandemics, tsunamis, earthquakes, etc. During these periods, the pressure is bigger for 
women and children. The impact of the novel coronavirus on the whole world tends to be profound in domestic violence, transforming itself into a hidden pandemic.

\section{The shadow pandemics}

Since March 2020, the media emphasized the fact that the number of domestic violence cases increased all around the world. Due to multiple restrictions, the victims could contact neither the associations who fight for women's rights and the elimination of domestic violence, police, or medical staff. The Executive Director of UN Women, Phumzile Mlambo-Ngcuke, labeled violence against women the `shadow pandemic` because everybody is concentrated in the first place on how to prevent the expansion of the virus or on finding a solution in order to combat it and during this time, one of the most profound consequences of the lockdown slowly advances, becoming itself a real pandemic. Meanwhile, the number of domestic violence cases increased, the media, the authorities, and the institutions were concentrated on the medical crisis related to the infection with the novel virus. The Regional Director of WHO, Hans Kluge, stated on May 7, 2020, that "WHO is deeply troubled by the reports from many countries .... of increases in interpersonal violence, including violence against women and men, by an intimate partner and against children - because of the COVID-19 response" (Mahase, 2020).

Starting with China, where the restrictions were imposed for the very first time, the social isolation created a perfect storm in many families. "Isolation paired with psychological and economic stressors accompanying the pandemic as well as potential increases in negative coping mechanisms can come together" (Usher et al., 2020, p. 550) in order to create an enormous domestic violence wave. Many countries from Europe, Latin America, Asia, and Africa underlined the rise in what concerns the number of domestic violence victims or, moreover in what concerns the femicides. "As a whole, China, Italy, Spain, France, India, Australia, United Kingdom, USA, Argentina reported a 60\% increase in calls to victim support lines" (Dejtiar \& Blank, 2020, p. 2).

In order to explain this dramatic phenomenon, researchers analyzed some factors that led to the recrudescence of violence in many families around the world. First, it could be noticed that as a measure to protect children not to get sick, the authorities decided that the schools, the kinder gardens, and the nurseries should be closed. On the same path, the parents started to work from home, and here began the struggle between taking care of children who need to study online and 
the tasks received at work that had to be done as soon as possible. The burden was more difficult for women who normally assisted the children in their online activity, who needed to deal with the household chores and, at the same time, had to finish until the deadline their work activities. This context led to "intrafamily changes and adaptations, adult stress, more strained interpersonal relationships and physically and psychologically damaging behaviours" (Dejtiar \& Blank, 2020, p. 2). Also, many households needed to deal with the situation when one of the parents suffered a job loss, and the family's financial situation became sensitive.

This context leads to another factor that aggravated the situation of women during the pandemic. Unemployment or the reduced income, insufficient social support, and finally the increased consumption of alcohol or drugs at home (taking into consideration the fact that the bars and restaurants were closed), the uncertainty feelings made the perpetrator become more violent, crueler, more ruthless.

Also, the sexual abuse rate started to increase during the pandemic. "Despite the decreased desire to become pregnant, women have experienced logistical and political threats to contraception and abortion access during the COVID-19 pandemic" (Connor et al., 2020). Many of them did not have the possibility to procure the contraception pills because the perpetrator offered them neither the possibility of going to the pharmacy nor the money to get them online. So, the risk of unwanted pregnancies increased, and the possibility to benefit from the necessary health care decreased. There is also another situation in which women may find the possibility to obtain the medical prescription to use "mifepristone - one of the drugs used in what concerns the abortions, but it is subjected to Risk Evaluation and Mitigation Strategy restrictions" (Connor et al., 2020). As a matter of fact, women must go to the hospital, and a doctor should analyze the situation and decide. So, the risk of contracting the virus is higher, and in many situations, the patients who do not represent emergency cases are not the first on the list when it comes to health care during the pandemic.

Moreover, the lockdown climate represents a perfect moment for the perpetrator to use all his control methods and even find new forms appropriate to the situation. During the pandemic, many aggressors used the virus to motivate their behaviours. Many of them isolated the victim in order to protect herself from COVID-19. The isolation became synonymous with protection and love. Also, the aggressors limited the possibility of accessing social media tools, so the victims 
did not have the chance to speak with their friends, family, or ask for help from the police or to the non-governmental organizations or to the associations that fight against violence. Even if the victim managed to use her phone or her applications, the perpetrator monitored her activity carefully. So, the woman did not have any freedom: she could not go outside because of the virus; she could not be free indoors because of her partner.

Concerning the limited use of the Internet and social media and the checks made to see the content accessed by the victim, the aggressor disinformed the woman regarding the new types of measures taken by the Government and by the authorities. So, she did not have the chance to read or listen to herself the news or talk with others, and the only solution was to believe and respect all the perpetrator's statements. In many cases, the aggressor "limited the access to essential items, such as hand hygiene, disinfectants, and personal protective equipment" (Dejtiar \& Blank, 2020, p. 3). It was much easier right now for the violent man not to offer the necessary goods to his partner, motivating his decision by mentioning that the victim does not have to go outside and does not need any kind of protective equipment.

During this period, those women who hoped that they would finally manage to find a shelter and quit the violent partner realized it was quite impossible. Because of the new measures imposed, they worry about "their physical safety or experience additional mental or emotional distress, making even more difficult to create necessary space in the relationship and mitigate immediate risk for violence" (Peterman et al., 2020). So, even if it was hard in the normal situation for women to quit their homes together with their children, the pandemic made this decision harder and more difficult to put into practice. For many women, the order \#stayhome did not mean protection against the disease, but the worst nightmare, which could eventually lead to death because of the insufficient measures taken to protect them against their aggressor.

\section{Statistics on VAW around the world}

Several organizations and associations around the Globe tried in different manners to quantify the number of domestic violence cases during the COVID-19 pandemics. In Europe, the countries who insisted on the difficulties encountered because of the lockdown were Italy, Spain, and France. "It was estimated that domestic violence has increased with $30 \%$ in France and $18 \%$ in Spain" (Sharifi et al., 2020, p. 2377). Moreover, to help the victims of domestic violence, in the Spanish and French pharmacies, there a code was introduced throughout women could ask for 
protection, care, and support. So, in the United Kingdom, one of the organizations that fight against violence, "Refuge, reported that calls to the UK Domestic Violence Helpline increased by $25 \%$ in the seven days following the announcement of social distancing and lockdown measures by the government" (Bradbury-Jones \& Isham, 2020, p. 2047).

Likewise, Latin America, a region known for the high number of femicides and domestic violence cases, reported a significant growth during the lockdown. Generally speaking, "VAW in Latin America is a systemic issue. According to Gender Equality Observatory (GEO), 2559 women were victims of femicide in 2017" (Toledo, 2020). In Mexico, "the highest number of domestic violence cases was registered in March and comparing the first six months of 2020 with those of 2019, it can be observed a 25\% increase during the pandemic" (Vasquez Correa, 2020, p. 135). Moreover, many victims tried to reach the associations via mobile phone or using social media to get help in Mexico. In Argentina, emergency calls for domestic violence have increased by $25 \%$ since the lockdown started" (Ndedi, 2020). In addition to that, in Brazil, it was perceived as a massive change considering the domestic violence situation. Considering the information provided by the Ministry for Women, Family and Human Rights, there was a "17\% increase in the number of calls denouncing violence against women in March 2020, when the recommendation for social distancing first issued in the country" (Souza Marques et al., 2020). In Peru, a country that depicts violence against women as a significant national problem, the pandemics emphasized this issue. The research and the studies have shown a "48\% increase of phone calls to the emergency lines since the beginning of the crisis" (Aguero, 2020). Also, in Columbia, the District Secretariat of Women from Bogota indicated that domestic violence became a real emergency during the medical crisis: "during the lockdown period, the number of cases increased by 230\%" (Espinosa-Bejarano, 2020, p. 182).

In Australia, the United States of America, and China, the enormous growth in domestic violence cases was also observed. Besides the strategies used generally by the perpetrators, they found new ones, according to the emergency. It was much easier for them to exercise coercive control at home and manipulate the victim to obtain what they want.

The international and European organizations are really implicated in this fight against violence during pandemics. On October 29, 2020, the European Institute of Gender Equality presented the Gender Equality Index in Europe. During the conference organized to reveal the 
researchers' discoveries, it was stated that there are not for the moment specific numbers concerning the violence against women. It is hard for the moment to provide correct statistics because the phenomenon is difficult to measure. Its real consequences will be perceived in the future, and its implications are not evanescent. However, the Institute underlined that the "lockdowns imposed across all Member States heightened the threat to women victims of violence" (European Institute for Gender Equality, 2020).

Also, the United Nations published documentation that insists on the negative aspects that affected the women during the COVID-19 pandemic. Besides the economic and health care aspects, the international organization emphasizes VAW's impact on a global scale. In their reports, it is stated, as in the case of EIGE, that it is still too early for exact and correct numbers. Yet, there were remarked in countries with adequate monitoring systems: "upwards of $25 \%$ in some countries and in other ones the reported cases have doubled" (United Nations, 2020). Moreover, it is stated that the pandemic intensified the consequences of VAW all around the world. UN indicates its policy is directed, during those hard times, on the governments' measures to help the women and the girls and prioritize the decisions, actions, and efforts made for those who suffer.

\section{How can the system help the victims during a pandemic?}

First, according to the situation observed during the crisis, it was noticed that telemedicine could have a positive impact, helping those victims that need assistance. This aspect was underlined, particularly in what concerns the normal pregnancy consultations: a doctor could offer an online consultation and, if necessary, prescribe the required medication in order to help the patient. On the same path, the doctor could prescribe contraceptives, abortion medication, and could counsel the woman, eliminating the possibility of SARS-COV-2 infection.

Secondly, there should be created online campaigns whose message could reach as many people as possible. The institutions should collaborate with the associations to deliver useful information that should aid the people in need. For instance, introducing specific codes that could be used in emergencies - as was the case in the pharmacies from Spain and France - represents a useful measure. The police, the social assistants, the doctors, and the lawyers should also know these codes. 
Moreover, the number of shelters must be increased in order to offer the chance to be protected to as many women and children. Especially in this kind of situation, an alert system becomes a necessity for the victim. Having the possibility to announce the services, the high risk of danger could save many human beings' lives. The governmental and non-governmental organizations should use specific online tools to facilitate the link between the authorities and the victim.

Even though the governments were overwhelmed initially because of the medical crisis and finally discovered that behind the COVID-19 crisis, there is hidden a silent pandemic, in their programs must be included clear measures that could help the risky categories during emergencies. Financial aids must be offered, "putting women at the forefront of the political planning and building capacity of main services to progress quality of response" (Sharifi et al., 2020, p. 2378) towards the crisis could be big achievements.

\section{Conclusions}

The COVID-19 pandemic, like all-natural disasters, in general, demonstrated the weaknesses of different systems from many perspectives. It emphasized the fear and uncertainty, which provided the perfect environment for different types of misdemeanors. Analyzing the disastrous effects of domestic violence in the first months of 2020, it can be stated that the authorities should invest large sums of money in improving the quality of public services. The high number of domestic violence cases demonstrates many changes to be done to keep the situation under control. Collaborations between the associations and the public institutions are mandatory for maintaining a low level of violence.

The lockdown demonstrated once again that the most dangerous place for women is their own home, the place where they have barely any chance to escape from the pressure, tension, control, abuse, and finally, death. If a lockdown is imposed, the authorities should find specific measures and solutions to protect the risky categories. A gender-inclusive approach is mandatory to be included and respected in all domains to go in the right direction.

\section{References}

Aguero, J. (2020). COVID-19 and the rise of intimate partner violence. World Development, 137(105217). https://www.ncbi.nlm.nih.gov/pmc/articles/PMC7522673/ https://doi.org/10.1016/j.worlddev.2020.105217 
Bradbury-Jones, C., \& Isham, L. (2020). The pandemic paradox: The consequences of COVID19 on domestic violence. Journal of Clinic Nursing, 29(13-14), 2047-2049. https://doi.org/10.1111/jocn.15296

Brooks, S., Webster, R., Smith, L., Woodland, L., Wessley, S., Greenberg, N., \& Rubin, G. J. (2020). The psychological impact of quarantine and how to reduce it: Rapid review of the evidence. Rapid Review, 395(10227), 912-920. https://doi.org/10.1016/S01406736(20)30460-8

Campbell, A. (2020). An increasing risk of family violence during the COVID-19 pandemic: Strengthening community collaborations to save lives. Forensic Science International: Reports, 2 (100089). https://doi.org/10.1016/j.fsir.2020.100089

Connor, J., Madhavan, S., Mokashi, M., Amanuel, H., Johnson, N., Pace, L., \& Bartz, D. (2020). Health risks and outcomes that disproportionately affect women during the COVID-19 pandemic: A review. Social Science and Medicine, 266(113364). https://doi.org/10.1016/j.socscimed.2020.113364

Defining Violence against Women and Girls (2010, October 31) Center To End Violence Against Women And Girls. Retrieved September 20, 2020, from https://www.endvawnow.org/en/articles/295-defining-violence-against-women-andgirls.html.

Dejtiar Waksman, R., \& Blank, D. (2020). The importance of domestic violence in times of COVID-19. Residencia Pediatrica, 10 (2), 1-6.

doi: 10.25060/residpediatr-2020.v10n2-414

Espinosa-Bejarano, M. (2020). Enemigo silente durante la pandemia COVID-19 en Colombia : La violencia contra la mujer"[Silent enemy during the COVID-19 pandemic in Colombia:Violence against women]. Salutem Scientia Spiritus, 6(1), 181-186. https://revistas.javerianacali.edu.co/index.php/salutemscientiaspiritus/article/view/2368

European Institute for Gender Equality. (2020, October). Gender Equality Index 2020: Digitalisation and the future of work European Institute for Gender Equality. Retrieved September 19, 2020, from https://eige.europa.eu/publications/gender-equality-index2020-digitalisation-and-future-work 
Kofman, Y., \& Garfin, D. R. (2020). Home is not always a haven: The Domestic violence crisis amid the COVID-19 pandemic. Psychological Trauma: Theory, Research, Practice, and Policy, 12(S1), 1998-2001. https://doi.org/10.1037/tra0000866

Liu, Y. C., Kuo, R. L., Shih, S. R., (2020). COVID-19: The first documented coronavirus pandemic in history, Biomedical Journal, 43(4), 328-333.

doi: 10.1016/j.bj.2020.04.007

Mahase, E. (2020). COVID-19: EU States report 60\% rise in emergency calls about domestic violence, BMJ (Clinical research ed.), 369. DOI: 10.1136/bmj.m1872.

Ndedi, A. (2020). Framework in ending violence against women and girls with the advent of the COVID-19 from an African perspective. Retrieved September 9, 2020, from https://papers.ssrn.com/sol3/papers.cfm?abstract_id=3575288

Peterman, A., Potts, A., O'Donnell, M., Thompson, K., Shah, N., Oertelt-Prigione, S., \& Van Gelder, N., (2020). Pandemics and violence against women and children. Center for Global Development, Working Paper 528.

https://www.cgdev.org/publication/pandemics-and-violence-against-women-and-children

Porta, M. (2016). A Dictionary of Epidemiology $\left(6^{\text {th }}\right.$ ed.). Oxford University Press. DOI:10.1093/acref/9780199976720.001.0001

Reynolds, M, \& Weiss, S. (2020, May 27). How coronavirus started and what happens next, explained. Retrieved September 19, 2020, from https://www.wired.co.uk/article/chinacoronavirus

Segato, R. L. (2016). Patriarchy from margin to center: Discipline, territoriality, and cruelty in the apocalyptic phase of capital. South Atlantic Quarterly, 115(3), 615-624. https://doi.org/10.1215/00382876-3608675

Sharifi, F., Larki, M., \& Roudsari, R. L. (2020). COVID-19 Outbreak as a threat of violence against women. Journal of Midwifery and Reproductive Health, 8(3), 2376-2379. https://doi.org/10.22038/jmrh.2020.16036

Souza Marques, E., Leite de Moraes, C., Hasselmann, M. H., Ferreira Deslandes, S., \& Reichenheim, M. E. (2020). Violence against women, children, and adolescents during the COVID-19 pandemic: Overview, contributing factors, and mitigating measures. Cadernos de Saude Publica, 36 (4). https://doi.org/10.1590/0102-311X00074420

Postmodernism Problems/Проблеми на постмодерността Vol. 10, No. 3, 2020, ISSN: 1314-3700, https://pmpjournal.org https://doi.org/10.46324/PMP2003277 
Toledo, Y. M., (2020). Representing violence against women in Latin American Media. The International Encyclopedia of Gender, Media, and Communication. https://doi.org/10.1002/9781119429128.iegmc320

United Nations. (2020, April 9). The Impact of COVID-19 on Women. Retrieved September 18, 2020, from https://www.un.org/sexualviolenceinconflict/wpcontent/uploads/2020/06/report/policy-brief-the-impact-of-covid-19-on-women/policybrief-the-impact-of-covid-19-on-women-en-1.pdf

Usher K., Bhullar, N., Durkin, J., Gyamfi, N., Jackson, D. (2020). Family violence and COVID19: Increased vulnerability and reduced options for support. International Journal for Mental Health Nursing, 29(4), 549-552. https://doi.org/10.1111/inm.12735

Vasquez Correa, L., (2020). Violencias contra las mujeres en el contexto de la COVID-19: Escenarios y desafios, Espacio I+D [Violence against women in COVID-19: Scenarios and challenges, Espacio I + D]. Innovacion mas desarrollo, 9(25), 129-144. Retrieved September 16, 2020, from

http://idbdocs.iadb.org/wsdocs/getdocument.aspx?docnum=EZSHA

Welzer-Lang, Daniel (2005). Arrête! Tu me fais mal, La violence domestique en 60 questions et 59 réponses [Stopped! You're hurting me. Domestic violence in 60 questions and 59 answers]. Petite Bibliothèque Payot.

Wenham, C., Smith, J., Davies S., Feng, H., Grepin, K., Harman, S., Herten-Crabb, A., \& Morgan R. (2020, July 8). Women are most affected by pandemics - lessons from past outbreaks. Retrieved September 29, 2020, from https://www.nature.com/articles/d41586020-02006-z\#ref-CR2

Wetsman, N. (2020, November 4). Everything you need to know about coronavirus. Stay alert, and be prepared. The Verge. Report. https://www.theverge.com/2020/1/23/21078457/coronavirus-outbreak-china-wuhanquarantine-who-sars-cdc-symptoms-risk 